\title{
Correction to: Three-dimensional changes in the location of soft tissue landmarks following bimaxillary orthognathic surgery
}

\author{
Gökhan Çoban' · İbrahim Yavuz' • Ahmet Emin Demirbaş²
}

Published online: 10 May 2021

(c) Springer Medizin Verlag GmbH, ein Teil von Springer Nature 2021

\section{Erratum zu: Dreidimensionale Veränderungen der Lage von Weichgewebereferenzpunkten nach bimaxillärer orthognatischer Chirurgie}

\section{Correction to:}

J Orofac Orthop 2021

https://doi.org/10.1007/s00056-021-00279-1

The original version of this article contained two spelling mistakes:

1. In the figure legend $3 b$, the word "Ppostoperative" is misspelled; correct is: "Postoperative".

2. In table 3 , column 5 , line 1 , the word "ret-back" is misspelled; correct is: "set-back".

The original article has been corrected.

Publisher's note Springer Nature remains neutral with regard to jurisdictional claims in published maps and institutional affiliations.

The online version of the original article can be found under https://doi.org/10.1007/s00056-021-00279-1.

Gökhan Çoban

dtgokhancoban@hotmail.com

1 Department of Orthodontics, Faculty of Dentistry, Erciyes University, 38039 Melikgazi, Kayseri, Turkey

2 Department of Maxillofacial Surgery, Faculty of Dentistry, Erciyes University, Kayseri, Turkey 
Hier steht eine Anzeige.

Springer 